\title{
Zinc Finger Protein Ubi-D4
}

National Cancer Institute

\section{Source}

National Cancer Institute. Zinc Finger Protein Ubi-D4. NCI Thesaurus. Code C157309.

Zinc finger protein ubi-d4 (391 aa, $44 \mathrm{kDa}$ ) is encoded by the human DPF2 gene. This protein plays a role in transcriptional regulation and DNA binding. 